Jonathan Elmer

\section{Inclusion and Exclusion of the Indian in the Early American Archive}

Abstract: Resurgence of interest in theories of sovereignty reflect both the availability of theoretical models capable of handling the paradoxes of inclusion and exclusion and historical sensitivity to the ways in which sovereignty develops in tandem with experiences of intercultural contact and conflict. The essay argues that one striking historical example of the interrelation of concepts of sovereignty, inclusion and exclusion, and cultural contact, lies in early American attempts to process the Native American »other « Using a widely influential speech recorded by Thomas Jefferson, the essay proposes first a literary interpretation of the text's power, and then suggests the way in which the theoretical argument about sovereignty delineated by Agamben (1998) can help elucidate the sanomaly" of Indian sovereignty in the American archive. A final section proposes that sovereignty, as developed in this intercultural context, promotes confusion between social and psychic systems, for which reason Luhmann's systems theory may fruitfully be supplemented by the psychoanalytic theory of Lacan as interpreted by Zizek (1991).

There are a range of theories available today that are equipped to examine the constitutiveness, and instability, of the distinction between the included and the excluded: Derridean deconstruction, versions of post-structuralist psychoanalytic theory (as for instance the different rereadings of Lacan in the work of Zizek and Laclau), or Luhmann's systems theory, especially as that embraces the paradoxes of closure and autopoiesis. This situation in contemporary theory may help explain what appears to be a resurgence of interest in the classical concept of political sovereignty. Already many years ago, the researches of Koselleck (1959) and Foucault (1975), in describing the auto-destruction or surpassing of classical concepts and conditions of sovereignty, implied its limited relevance to the conditions of modernity. ${ }^{1}$ But in recent years, attempts to grasp the specificity of current global structures of power have led writers to reengage with the classical paradoxes of sovereignty - thus Zizek (1991) rereads Hegel on the monarch, Agamben (1995) looks back to Hobbes and Schmitt, and Hardt and Negri (1999) reassess Bodin, among others. It might

1 Foucault (1990, 85-86): »it is a power whose model is essentially juridical, centered on nothing more than the statement of the law and the operation of taboos. All the modes of domination, submission, and subjugation are ultimately reduced to an effect of obedience. Why is this juridical notion of power, involving as it does the neglect of everything that makes for its productive effectiveness, its strategic resourcefulness, its positivity, so readily accepted? « appear that, just as Locke's eff ply distributed sovereign po involved in historical social $t$ absolutist model, has merely $p$ When confronted with the que sovereignty is due primarily to tions, or to refinements in cor one is inclined to answer the structures of political power in ways in which sovereignty, anc nation and international law, responses to transcultural con ficiently emphasized, we mig perspective defines the presen historically and conceptually ment in the cultural semantic mourning the extinction of $h$ problem of sovereignty, and sion.

I begin at the most concrete 1 tion for my title. In 1774 the land-jobbers along the Ohi whom one John Logan (Tahdisplaced Cayuga, or Mingo. of murders supervised by one which members of Logan's fa riety than it might otherwise by Chief Logan at the conclu recalled, Logan's speech b Williamsburgh particularly, ar cers resided or resorted.« But of-mouth notoriety. Jefferson to copy it in his "pocket-bool public papers of the continer cal publications of Great Bri

2 Thus Locke $(1690,9)$, in invoki with respect to it: "the execution hands «. 


\section{lian in the}

ereignty reflect both the availability of theo$s$ of inclusion and exclusion and historical lops in tandem with experiences of interculne striking historical example of the interrexclusion, and cultural contact, lies in early $n$ »other, « Using a widely influential speech ; first a literary interpretation of the text's eoretical argument about sovereignty delin$e$ sanomaly " of Indian sovereignty in the vereignty, as developed in this intercultural ychic systems, for which reason Luhmann's by the psychoanalytic theory of Lacan as

lay that are equipped to examine the stinction between the included and rersions of post-structuralist psychoit rereadings of Lacan in the work of $s$ theory, especially as that embraces This situation in contemporary thea resurgence of interest in the classily many years ago, the researches of describing the auto-destruction or tions of sovereignty, implied its limiity. ${ }^{1}$ But in recent years, attempts to ictures of power have led writers to of sovereignty - thus Zizek (1991) a (1995) looks back to Hobbes and ssess Bodin, among others. It might

del is essentially juridical, centered on nothperation of taboos. All the modes of dominareduced to an effect of obedience. Why is this neglect of everything that makes for its pro3, its positivity, so readily accepted? « appear that, just as Locke's effort to move beyond Hobbesian absolutism simply distributed sovereign power more widely, ${ }^{2}$ Foucault's call for those involved in historical social theory to overcome their fascination with the absolutist model, has merely proliferated its presence at other levels.

When confronted with the question whether the persistence of the concept of sovereignty is due primarily to its relevance to contemporary historical conditions, or to refinements in contemporary theory and in accounts of the past, one is inclined to answer the latter. In particular, the felt need to think about structures of political power in transnational terms has renewed interest in the ways in which sovereignty, and its corollary developments in definitions of the nation and international law, themselves developed historically in, and as, responses to transcultural contact, colonization, and conquest, a history insufficiently emphasized, we might suggest, by Koselleck and Foucault. Such a perspective defines the present essay, in any case. In what follows, I will situate historically and conceptually a particularly important and enduring development in the cultural semantics of early America - the trope of the last Indian mourning the extinction of his people - and I will do so by reference to the problem of sovereignty, and its attendant paradoxes of inclusion and exclusion.

I begin at the most concrete level, with the text from which I draw the inspiration for my title. In 1774 there was a bloody months-long conflict between land-jobbers along the Ohio and local Indians, largely Shawnee, among whom one John Logan (Tah-Ga-Jute) was living, although himself by birth a displaced Cayuga, or Mingo. Hostilities were apparently provoked by a series of murders supervised by one Michael Cresap, or endorsed by him, actions in which members of Logan's family were killed. This conflict gained more notoriety than it might otherwise have done primarily because of the speech made by Chief Logan at the conclusion of peace in the autumn of 1774. As Jefferson recalled, Logan's speech became the stheme of every conversation, in Williamsburgh particularly, and generally, indeed, wheresoever any of the officers resided or resorted. «But Logan's speech quickly went beyond mere wordof-mouth notoriety. Jefferson himself, ever the inscriber, thought enough of it to copy it in his »pocket-book, « and very soon the speech »flew through all the public papers of the continent, and through the magazines and other periodical publications of Great Britain« $(1982,227)$. Even before Jefferson gave it a

2 Thus Locke $(1690,9)$, in invoking a law of nature, makes everyone the potential sovereign with respect to it: sthe execution of the law of nature is, in that state, put into every man's hands«. 
special prominence in Notes, it had penetrated the colonial culture deep enough to serve as a »school exercise for repetition « (Jefferson 1982, 227), and it retained a special status well into the middle of the nineteenth century, serving as a set-piece for schoolroom oratory in McGuffey's Fourth and Fifth Readers. Above and beyond the specific uses of Logan's name and speech, however, the text can be interpreted as the earliest influential instance of a peculiarly enduring trope - the last of the $X$, the Indian facing and bewailing his people's extinction. One can trace Logan's legatees, therefore, in a wide variety of nineteenth and twentieth century representations of Indians; it is not surprising, for instance, that his name is invoked in the preface to Theodora Kroeber's anthropological classic of 1961, Ishi: A Biography of the Last Wild Indian in North America.

Here is the text of the speech as recorded by Jefferson:

I appeal to any white man to say, if ever he entered Logan's cabin hungry and he gave him not meat; if ever he came cold and naked, and he clothed him not. During the course of the last long and bloody war, Logan remained idle in his cabin, an advocate for peace. Such was my love for the whites, that my countrymen pointed as they passed, and said, >Logan is the friend of the white men.< I had even thought to have lived with you, but for the injuries of one man. Col. Cresap, the last spring, in cold blood, and unprovoked, murdered all the relations of Logan, not sparing even my women and children. There runs not a drop of my blood in the veins of any living creature. This called on me for revenge. I have sought it: I have killed many: I have fully glutted my vengeance. For my country, I rejoice at the beams of peace. But do not harbour a thought that mine is the joy of fear. Logan never felt fear. He will not turn on his heel to save his life. Who is there to mourn for Logan? - Not one. (Jefferson 1982, 63)

I have analyzed this speech elsewhere as an example of the sethnic sublime (Elmer 1998). We recall that Kant had proposed two versions of the sublime, dynamic and mathematical, the first turning essentially on the affective disturbances created by exhibitions of power, the second on the difficulty of comprehending temporal series or magnitudes beyond human powers of apprehension. In the ethnic sublime, something quite like these two registers appear as the axes of affect and historicity. For Euro-American discourse, very little was more fascinating than the affective comportment of Indians. Indians were represented, sometimes within sentences of each other, as both unimaginably violent in their affective responses (codes of vengeance were here a favorite topic), and as preternaturally controlled and stoical (here the uncomplaining endurance of physical hardship, on the hunt or under torture, were time and again described). But correlative to this effort to fix the Native American according to schemes of affectivity was the effort to fix them in time. As many historians have noted, the me New World posed a puzzle: $v$ history? The problem with th problem of the "first one, « an cases like the Kennewick mar extreme affect, however, this converted, via what I called $t$ cious attention to his end; $t$ condemned him. The first on I can demonstrate this proces work of one of Logan's most Twain (1967) famously charg. of fiction-writing, namely th characters from the dead one ans, this confusion obeys a c perfectly clear in the closing ing the funeral obsequies fo book's title reaches peak poi ture as to have been a cliché it may at first seem. The nove Chingachgook (Cooper 198 son, the phrase takes on a co last few - both father and sc nund's displaced Delawares, fication of »last « moves from collective reference is the $\mathrm{e}$ Uncas signifies the foreclosu back, as it were, from a singl the Europeans had such dif nation, eventually to race. $T$ only as a feint: his patheti »zero« - the »last « already $\mathrm{f}$ Uncas's death, this double $f$ self must now be the one $b$ one: $»$ Seated, as in life, with composure, Uncas appearec was placed. ... So riveted ar

3 The "Kennewick Man « is the $\mathrm{n}$ in 1996 in Kennewick, Washing nificance of, and control over, various scientists, with the nati kennewick. 
netrated the colonial culture deep repetition « (Jefferson 1982, 227), and iddle of the nineteenth century, servin McGuffey's Fourth and Fifth ReadLogan's name and speech, however, $t$ influential instance of a peculiarly ian facing and bewailing his people's i, therefore, in a wide variety of ninetions of Indians; it is not surprising, the preface to Theodora Kroeber's Biography of the Last Wild Indian in

\section{by Jefferson:}

ever he entered Logan's cabin ver he came cold and naked, and of the last long and bloody war, advocate for peace. Such was my nen pointed as they passed, and te men.< I had even thought to ies of one man. Col. Cresap, the oked, murdered all the relations $\mathrm{n}$ and children. There runs not a iving creature. This called on me led many: I have fully glutted my $t$ the beams of peace. But do not of fear. Logan never felt fear. He life. Who is there to mourn for

an example of the »ethnic sublime oposed two versions of the sublime, ig essentially on the affective disture second on the difficulty of compreeyond human powers of apprehenite like these two registers appear as -American discourse, very little was rtment of Indians. Indians were repf each other, as both unimaginably $s$ of vengeance were here a favorite and stoical (here the uncomplaining unt or under torture, were time and effort to fix the Native American e effort to fix them in time. As many historians have noted, the mere fact of the priority of indigenous people in the New World posed a puzzle: where did these people belong in the scheme of history? The problem with the Indian, in this line of inquiry, was always the problem of the »first one, « an issue that remains alive and well, by the way, in cases like the Kennewick man. ${ }^{3}$ As with the predilection for representations of extreme affect, however, this need to inscribe the Indian's origin is regularly converted, via what I called the sublime conversion of the »one, « into a ferocious attention to his end; the inevitable extinction to which this discourse condemned him. The first one is converted into the last one.

I can demonstrate this process most clearly, perhaps, via a detour through the work of one of Logan's most famous legatees, James Fenimore Cooper. Mark Twain (1967) famously charged Cooper with ignoring one of the cardinal rules of fiction-writing, namely that readers should be able to distinguish the live characters from the dead ones. But when it comes to the presentation of Indians, this confusion obeys a certain grim logic, something that Cooper makes perfectly clear in the closing moments of The Last of the Mohicans (1826), during the funeral obsequies for Uncas and Cora, when the cruel irony of the book's title reaches peak poignancy. This phrase, so fully absorbed in U.S. culture as to have been a cliché for nearly two centuries, is more ambiguous than it may at first seem. The novel early on applies the phrase to Uncas, only son of Chingachgook (Cooper 1986, 33). But by the end, as the father mourns the son, the phrase takes on a collective, inclusive sense: the "last « now means the last few - both father and son, certainly, but it also seems to embrace Tamenund's displaced Delawares, who claim Uncas as their own. The way the signification of »last« moves from the singular terminal point of a series to a more collective reference is the essence of its power, of course. The extinction of Uncas signifies the foreclosure of the group's futurity - and thus »last« carries back, as it were, from a single linear point to all the collective designations that the Europeans had such difficulty distinguishing, back to family, to tribe, to nation, eventually to race. The heroic singularity of Uncas is thus crucial, but only as a feint: his pathetic »one « is only pathetic because it means both "zero « - the »last« already has one foot in the void - and »at least two. « With Uncas's death, this double function falls back onto Chingachgook, who himself must now be the one both dead and alive, less than one and more than one: "Seated, as in life, with his form and limbs arranged in grave and decent composure, Uncas appeared. ... Directly in front of the corpse, Chingachgook was placed. ... So riveted and intense had been that gaze, and so changeless

3 The »Kennewick Man« is the name given to skeletal remains of very ancient date discovered in 1996 in Kennewick, Washington. For a synopsis of the ongoing controversy about the significance of, and control over, the remains, a controversy pitting Native Americans against various scientists, with the national government as mediator, see http://www.cr.nps.gov/aad/ kennewick. 
Inclusion and Exclusion of the Indian

his attitude, that a stranger might not have told the living from the dead ... (Cooper 1986, 340).

This stony face-to-face of father and son leads to what Cooper calls, in a phrase that might apply just as well to Logan, the »monody of the father" $(1986,345)$. All eyes and ears are turned toward Chingachgook: »But they listened in vain. The strains rose just so loud, as to become intelligible, and then grew fainter and more trembling, until finally they sunk on the ear, as if borne away by a passing breath of wind. The lips of the Sagamore closed, and he remained silent in his seat, looking, with his riveted and motionless form, like some creature that had been turned from the Almighty hand with the form, but without the spirit of a man « (Cooper 1986, 345). Chingachgook's »monody« remains fundamentally ambiguous, and we can interpret this ambiguity, I think, as a semantic and affective counterpart to the temporal ambiguity of the »last. « Both in and out of the series, Chingachgook's mourning both is and is not »intelligible. « Its passing, »as if borne away by a passing breath of wind,$\ll$ is a subsidence into the land itself, a petrifaction into a species of divine statuary »turned from the Almighty hand, « a ruin or remnant. But this sublime conversion is never entirely effective: the »one « produced remains caught up in a discursive constraint that requires that both his singularity as the end of the series and his affective posture do not remain entirely quarantined, but rather become ambiguously communicable - his »lastness « extends to others, his mourning broaches, if only just, the edge of the »intelligible.« Readers of Cooper will remember that Chingachgook appears in The Last of the Mohicans in a resurrected form, having already perished in another subsidence into nature, the conflagration at the end of The Pioneers (1823). Cooper's resurrection of his dying Indians, so that they can die again, is exemplary of a repetition at work in U.S. cultural history, which keeps bringing back the Indians so that they can vanish again, keeps inscribing them as an appearance disappearing.

Logan's speech, too, attempts to provoke a pathos in which one can participate at a distance, and it manages this, moreover, according to the logic of sublime conversion I have already delineated with respect to Cooper. Logan stands as a synecdoche not so much for Indians in their totality, however, than for the unfinished social and historical convulsions issuing from contact and violence between Euro-Americans and Indians. Through his speech, with its reference to a peace simultaneously accepted and personally repudiated, Logan's indexing of the origin of conflict, and of the priority of Native Americans, is converted for a white audience into the end of that conflict, an end both wishful and melancholy. Like Chingachgook, Logan's sublimity arises from his singularity. And like Chingachgook, that singularity must be both asserted and negated. In order for the one to signify a zero, he must be inscribed. He must both accept a peace, even an extinction, while at the same 
ve told the living from the dead ... «

leads to what Cooper calls, in a ogan, the smonody of the father" oward Chingachgook: »But they lis, as to become intelligible, and then ally they sunk on the ear, as if borne ps of the Sagamore closed, and he is riveted and motionless form, like the Almighty hand with the form, $1986,345)$. Chingachgook's "monand we can interpret this ambiguity, erpart to the temporal ambiguity of lingachgook's mourning both is and orne away by a passing breath of a petrifaction into a species of divine s a ruin or remnant. But this sublime "one s produced remains caught up it both his singularity as the end of t remain entirely quarantined, but e - his "lastness « extends to others, tge of the »intelligible.« Readers of : appears in The Last of the Mohicans rished in another subsidence into Pioneers (1823). Cooper's resurrecdie again, is exemplary of a repetikeeps bringing back the Indians so 5 them as an appearance disappear-

a pathos in which one can particinoreover, according to the logic of ted with respect to Cooper. Logan dians in their totality, however, than nvulsions issuing from contact and dians. Through his speech, with its septed and personally repudiated, and of the priority of Native Amerito the end of that conflict, an end gachgook, Logan's sublimity arises ook, that singularity must be both one to signify a zero, he must be ren an extinction, while at the same time exempting himself, singularly, from it: »For my country, I rejoice at the beams of peace. But do not harbour a thought that mine is the joy of fear. Logan never felt fear. He will not turn on his heel to save his life. Who is there to mourn for Logan? - Not one. « As a matter of reference, Logan's »not one» refers to a zero, the end of the series, but as an inscription in an archive its negation carries a different force.

\section{II}

Let me move now to a more general historical level to suggest some further horizons in which to understand the power of this ambiguous inscription of the »not one.« For Logan's speech is more than just a source of later literary semantics, such as prevail in Cooper or many of his contemporaries. We can see it as a figural crystallization of a fundamental anomaly at the heart of the political and legal processing of Indians by the American state. »Anomaly « is the term Francis Paul Prucha (1994) applies to the history of treaty relations between Americans and Indians, in his recent study, American Indian Treaties: The History of a Political Anomaly. Logan's speech found its way into Jefferson's imagination and »pocket-book « because it seemed an unusually eloquent example of a genre well known to him: the Indian treaty oration (see Boyd 1938). Such treaties were themselves dependant on a concept of political sovereignty applied to the tribes, or »nations, « as they were known until well into the nineteenth century. This was not a situation peculiar to North America. We know, in general, how crucial the concept of sovereignty was in the long history of the articulation of European and indigenous political identity. The researches of Carl Schmitt (1950) and, more recently, Anthony Pagden (1986) have shown how even before the development of Statist concepts of sovereignty, prior notions of self-determination were crucial in formalizing something that might be called international law. In disabling the Aristotelian category of the »natural slave, « for example, Vitoria produced an early version of such an identity for natives in the Spanish dominions, who thereby became capable of being antagonists in a "just war " when, in resisting the free movements of Catholic missionaries, they denied the principle of »liberum commercium. " Later, as legal historian Charles Alexandrowicz (1967) has shown, the need to formalize trade relations with Southeast Asian sovereigns became, for Grotius among others, the provocation to elaborate further the idea of sovereignty in international law. The development of concepts of sovereignty, in other words, was importantly determined by interaction with non-Europeans.

In the English colonies of North America, and later, early U.S. dominions, sovereignty was attributed to the various tribal »nations « with which the Anglo- 
Americans had relations. As the balance of power shifted towards the settlers, however, the force of the concept became more and more dubious. By the time of Chief Justice Marshall's crucial decisions of the 1830's, the (il)logic of the inclusive exclusion had become uncomfortably visible: Marshall's compromise conclusion, that Indians were to be considered, in legal terms, »domestic dependent nations, « is rightly infamous, but it does, we might argue, face the paradoxical relation squarely. ${ }^{4}$ The entire history of treaties between Native Americans and the United States is entangled in this long and vexed discourse of sovereignty, even though tribes' sovereign powers were explicitly rejected in 1871 by a U. S. Congress weary of treaty-making. How do we explain the durability of this anomalous sovereignty? Sidney Harring's study of nineteenth century case law dealing with Indian sovereignty exposes a strange phenomenon: »Although the United States did not have to exercise great legal imagination in incorporating the Indian tribes within its boundaries, it made a great effort to do so « $(1994,8)$. The effort, one would have to say, was motivated not by any desire to treat Indians justly. As Harring puts it: "This riation's emphasis on law did not lead to results very different from those achieved with vicious Spanish bloodhounds. Law was used to perpetrate murder and land frauds of all sorts, and the legal rights of American Indians were ignored by state and federal courts. The product with the great concern with the slegality< of nineteenth-century federal Indian policy was genocide: more than 90 percent of all Native Americans died, and most native land was alienated, the balance occupied by Indians but >owned by the United States« $(1994,9)$. It is not surprising, I think, that faced with the ignominious history of treaties made and broken, authors veer toward a psychological or moral vocabulary, as I just did in using the word »ignominious. « Answering Vine DeLoria's charge, in his indignantly titled Custer Died for Your Sins, that "America has yet to keep one Indian treaty or agreement, « Prucha points out that many agreements have retained force over the years $(1986,28)$. But he can only explain this by matching De Loria's accusation of perfidy with what seems to me an egregious sanctimony: "What kept the anomaly of the treaties alive was the enduring quality in the American character that upheld the faith and honor of the nation « $(1994,16)$. If we shift the focus slightly, we might arrive at a more fruitful line of inquiry. Are Indians subject to federal and state law, or do they exercise sovereignty on tribal lands? From one vantage, we might be inclined to say, »both«: Indians are subject to federal and state law, but retain, in precarious form, certain sovereign rights on tribal (reservation) lands. But Harring's research suggests that the more accurate answer to the question »subject or sovereign? « might be "neither «: the overall effect of the concept of tribal sovereignty in the nineteenth century »left the tribes unprotected against the encroachment of local

4 Harring $(1994,22)$ refers to Marshall's prevarication as »so ambiguous as to be almost meaningless «. whites« (50). One cannot h treatment by the American 1 With this strange double tu included to be abandoned, I Giorgio Agamben's suggesti Homo Sacer. Agamben focus tion between the juridico-in $(1998,6)$. He traces the origi in Roman law known as the but who cannot be sacrificec tutional apparatus precisely argument that »the inclusio original - if concealed - nuc production of a biopolitical bo 6). Agamben's historical a analysis of various zones o centers, massive imprompt more and more to be con These are zones in which $i$ state calculations only as a Agamben's thesis has anot the inclusive exclusion of zones of abandonment cou. We might also consider the speech issues - as another takes us back to Logan, an tant, and typical, that Loge evidence of his social status ben elaborates what he ter of Carl Schmitt. The sovere same time inside and outs tees and founds the legal respect, the sovereign is th law that transcends positi 1998, 17). Elsewhere, Aga elaboration of the link betv of sovereignty, and does sc

5 "American Indians, along wit rigines share the awful distin American Indians are arreste compared to about 5 per 100 cans« (Harring 1994, 24). 
of power shifted towards the settlers, more and more dubious. By the time ms of the 1830's, the (il)logic of the rtably visible: Marshall's compromise nsidered, in legal terms, »domestic but it does, we might argue, face the history of treaties between Native gled in this long and vexed discourse ign powers were explicitly rejected in naking. How do we explain the duradney Harring's study of nineteenth reignty exposes a strange phenomehave to exercise great legal imaginaithin its boundaries, it made a great vould have to say, was motivated not rring puts it: »This nation's emphasis ent from those achieved with vicious serpetrate murder and land frauds of a Indians were ignored by state and $t$ concern with the slegality of ninegenocide: more than 90 percent of all and was alienated, the balance occud States« $(1994,9)$. It is not surprisuus history of treaties made and broor moral vocabulary, as I just did in gVine DeLoria's charge, in his indig"America has yet to keep one Indian that many agreements have retained in only explain this by matching De ems to me an egregious sanctimony: live was the enduring quality in the and honor of the nation « $(1994,16)$. If at a more fruitful line of inquiry. Are or do they exercise sovereignty on it be inclined to say, »both «: Indians tain, in precarious form, certain sovBut Harring's research suggests that on »subject or sovereign? « might be pt of tribal sovereignty in the nined against the encroachment of local tion as $" s o$ ambiguous as to be almost mean- whites « (50). One cannot help feeling that the deep "anomaly « of Indians' treatment by the American legal system is their abandonment by it. ${ }^{5}$

With this strange double turn wherein Indians are inscribed to be negated, included to be abandoned, I return now to the concept of »sovereignty, « and Giorgio Agamben's suggestive meditations on that concept in his recent book, Homo Sacer. Agamben focuses on what he calls the »hidden point of intersection between the juridico-institutional and the biopolitical models of power« $(1998,6)$. He traces the origin of the biopolitical body, or »bare life, « to a figure in Roman law known as the homo sacer - he who can be killed with impunity but who cannot be sacrificed, a figure that is included within the juridico-institutional apparatus precisely as excluded from it. It is Agamben's most general argument that $»$ the inclusion of bare life in the political realm constitutes the original - if concealed - nucleus of sovereign power. It can even be said that the production of a biopolitical body is the original activity of sovereign power (1998, 6). Agamben's historical analyses range widely, but they culminate in an analysis of various zones of abandonment - Nazi death camps, detainment centers, massive impromptu refugee holding areas - some of which seem more and more to be considered »normal« features of the political scene. These are zones in which individuals are reduced to »bare life, « included in state calculations only as abandoned by them. As I have begun to indicate, Agamben's thesis has another, equally powerful, historical example, namely the inclusive exclusion of Native Americans in the U.S.; Agamben's list of zones of abandonment could easily include the Indian »reservation. «

We might also consider the frontier - that strange location from which Logan's speech issues - as another version of the »zone of abandonment. "Such a turn takes us back to Logan, and his exemplification of the sovereign (it is important, and typical, that Logan is traditionally referred to as a Chicf, although evidence of his social status is ambiguous). In the first part of his book, Agamben elaborates what he terms the »sovereign exception, « largely via the work of Carl Schmitt. The sovereign, according to Schmitt, is located at one and the same time inside and outside the juridical order; he simultaneously guarantees and founds the legal order, and exceeds it (Agamben 1998, 15). In this respect, the sovereign is the exception that grounds the rule, san element in law that transcends positive law in the form of its suspension « (Agamben $1998,17)$. Elsewhere, Agamben explores this paradox in terms of Schmitt's elaboration of the link between »localization « and »ordering « in the extension of sovereignty, and does so moreover with reference to the historical status of

5 »American Indians, along with Canadian Indians, New Zealand Maoris, and Australian Aborigines share the awful distinction of being the most arrested and jailed people in the world. American Indians are arrested at a rate that approaches 40 per 100 of population per year, compared to about 5 per 100 for black Americans and just over 1 per 100 for white Americans« (Harring 1994, 24). 
the New World: »Schmitt shows how the link between localization and ordering constitutive of the nomos of the earth always implies a zone that is excluded from law and that takes the shape of a sfree and juridically empty space in which the sovereign power no longer knows the limits fixed by the nomos of the territorial order. In the classical epoch of the ius publicum Europaeum this zone corresponded to the New World, which was identified with the state of nature in which everything is possible (Locke: In the beginning, all the world was America') (Agamben 1998, 36). Such an observation returns us to the history that I just briefly evoked of the development of European sovereignty in relation to its outside. But Agamben further pressures Schmitt's paradox, to show why this process of expansion must necessarily take the form of a generalization of the state of exception: "The state of nature and the state of exception are nothing but two sides of a single topological process in which what was pressuposed as external (the state of nature) now reappears, as in a Möbius strip or a Leyden jar, in the inside (as state of exception), and the sovereign power is this very impossibility of distinguishing between outside and inside, nature and exception, physis and nomos. The state of exception is thus not so much a spatiotemporal suspension as a complex topological figure in which not only the exception and the rule but also the state of nature and law, outside and inside, pass through one another " $(1998,37)$. The »frontier « from which Logan's speech issues is, I would suggest, a concrete instance of this complex topological figure. The frontier is not "chaos, " pure randomness negating the localization-ordering activity of sovereignty. It is rather the projection or figure of a membrane, something »included in the juridical order « as a "zone of indistinction between outside and inside, chaos and the normal situation - the state of exception " (Agamben 1998, 19). Such an understanding of frontier as "zone of indistinction « helps make sense of the highly contradictory approach to the frontier and its inhabitants in American history. (Harring's work, moreover, suggests that the reservation, or indeed any area marked by an ambiguous native sovereignty, might also exemplify this "zone of indistinction «). Both native and white figures seem poised on this blurry line between physis and nomos, appearing sometimes as embodying essential features of civilization, at others as lawless wolves to one another. Logan, who »had even thought to have lived « with the white man, is an embodiment of this zone of indistinction, at once acknowledging nomos - to the point of rejoicing »at the beams of peace « that will temporarily restore order on the Virginia frontier and exempting himself, singularly, from it. More generally, then, we can take Logan's speech as exemplary of the way in which the frontier "zone of indistinction « is, as it were, the space in which attributions of sovereignty obey the strange topology of the excluded inclusion, such that sovereignty just »is this very impossibility of distinguishing inside and outside." The fact that sovereignty requires - or more precisely, is indistinguishable from - this zone of indistinction may suggest wh has been so important, even Logan's exemplary status is tion: the sovereign exempts in the concluded peace. Aga relation between example an the set insofar as it belongs precisely because it does no ture of projection and rejec would seem to bear on this sovereign exception, he is ar Agamben that »exception as mately indistinguishable anc the belonging and commona system, just as in every socia strangeness and intimacy, is

\section{III}

With this relation between concept of sovereignty, we at namely, the production, or noticed how the concept o course, between a designati and one that refers to the $\mathrm{i}$ might have historically play vidual, ${ }_{,}^{6}$ I will propose here $t$ eignty performs, namely, the individual and that of the co ity of individuals is to be de system and a social system words, on a species of psycl exemplary and the exception species of reduction that lec tions like »the Indian, « or $\mathrm{f}$ that Logan instantiates, em exception and the homo sace respect too, he becomes ex

6 See for one reference on a com] artificial man whose soul is sov 
ink between localization and orderways implies a zone that is excluded ree and juridically empty space in ows the limits fixed by the nomos of of the ius publicum Europaeum this lich was identified with the state of cke: >In the beginning, all the world an observation returns us to the hisopment of European sovereignty in her pressures Schmitt's paradox, to necessarily take the form of a generate of nature and the state of exceptopological process in which what of nature) now reappears, as in a (as state of exception), and the sovdistinguishing between outside and omos. The state of exception is thus I as a complex topological figure in but also the state of nature and law, her $(1998,37)$. The »frontier « from suggest, a concrete instance of this is not »chaos, « pure randomness - of sovereignty. It is rather the pro$g$ »included in the juridical order « as id inside, chaos and the normal situ$1998,19)$. Such an understanding of ake sense of the highly contradictory nts in American history. (Harring's tion, or indeed any area marked by so exemplify this "zone of indistinca poised on this blurry line between as embodying essential features of one another. Logan, who shad even $\mathrm{n}$, is an embodiment of this zone of os - to the point of rejoicing "at the tore order on the Virginia frontier : More generally, then, we can take $n$ which the frontier »zone of indisattributions of sovereignty obey the n, such that sovereignty just »is this and outside. « The fact that soverdistinguishable from - this zone of indistinction may suggest why its attribution to Native American communities has been so important, even down to the present day.

Logan's exemplary status is thus necessarily tied also to his status as exception: the sovereign exempts himself from the establishment of law and order in the concluded peace. Agamben has some fascinating pages on the logical relation between example and exception: »While the example is excluded from the set insofar as it belongs to it, the exception is included in the normal case precisely because it does not belong to it « $(1998,22)$. The complicated structure of projection and rejection at work in the archiving of Logan's speech would seem to bear on this relation. Inasmuch as Logan's speech dramatizes sovereign exception, he is an example of the exception. We can thus agree with Agamben that »exception and example are correlative concepts that are ultimately indistinguishable and that come into play every time the very sense of the belonging and commonality of individuals is to be defined. In every logical system, just as in every social system, the relation between outside and inside, strangeness and intimacy, is this complicated « $(1998,22)$.

III

With this relation between example and exception that oscillates within the concept of sovereignty, we are also returned to the problem I addressed earlier, namely, the production, or conversion, of the »one." The reader may have noticed how the concept of sovereignty has oscillated, throughout my discourse, between a designation proper to collectivities - nations, tribes, etc. and one that refers to the individual. Without exploring the role sovereignty might have historically played in the development of the concept of the individual, ${ }^{6} \mathrm{I}$ will propose here that this slippage is inherent in the function sovereignty performs, namely, the creation of a homology between the unity of the individual and that of the collectivity in which »the belonging and commonality of individuals is to be defined.« The highly unstable »coupling of a logical system and a social system « to which Agamben refers is dependent, in other words, on a species of psychological projection: this is what the play with the exemplary and the exceptional require, the production of summative unities, a species of reduction that leads to the usability, however objectionable, of fictions like »the Indian, " or for that matter, »the sovereign. I I have suggested that Logan instantiates, embodies, provides the figure for, both the sovereign exception and the homo sacer, he who has been reduced to »bare life.« (In this respect too, he becomes exemplary of the entire tradition of relations with

6 See for one reference on a complex topic: »The State is not only a vast mechanism, but also an artificial man whose soul is sovereignty« (Koselleck 1988, 35). 
Native Americans, which simultaneously imputes sovereignty to the Indian and reduces him to the status of bare life, included within the law as abandoned by it). It is thus not any merely literary affectation that places this representation within the context of extinction and mortality. Recall Agamben's most general thesis: "It can even be said that the production of the biopolitical body is the original activity of sovereign power. «The deathless sovereign produces, as its own inverted projection, the body stripped of any significance other than its mortality. When Logan says »Who is there to mourn for Logan? - Not one, « he gestures toward this bare life, for to be unmourned is to be the homo sacer, included within the social as abandoned by it, the terminus of the social itself, the way in which society thinks, includes but leaves alone, its own impossibility. What Agamben writes of the sovereign exception holds equally, according to the paradoxical topology he analyzes, for homo sacer, $\gg$ the figure in which singularity is represented as such, which is to say, insofar as it is unrepresentable« $(1998,24)$.

Such a thesis runs directly up against one of the foundational theoretical distinctions of Luhmann's systems theory, that between social systems and psychic systems. Indeed, it is to avoid the lures of psychological projection that Luhmann derives action from communication (as an attribution of communication), rather than the other way around (1995, 138ff). To speak, as I have done above, about society »thinking « its »impossibility « risks the confusion of psychic and social systems. »A social system cannot think; a psychological system cannot communicate (Luhmann 2002, 165). And surely the silence invoked by Logan in the figure of the end of mourning (»who is there to mourn for Logan? - Not one. «) has a fundamentally different »system reference « than the silence inscribed in the communication of social systems:

Only for the system of society that includes all communication does the silence produced along with it become a problem... Any other social system formed within society can start from the assumption that communication also takes place in the environment. What is not said in the system can still be communicated by other systems on other occasions with different words, concepts, metaphors. This does not apply to society. Its environment remains silent. And even this characterization as $»$ silence $\ll$ is still one of communication and one with reference to communication; for in reality ssilence " is not an operation outside of society but only a counter-image which society projects into its environment, or it is the mirror in which society comes to see that what is not said is not said. (Luhmann 1994, 33)

Projection, mirroring: such are the figures with which Luhmann aims to describe the manner in which a society, as communication, re-enters its own enabling distinction from an environment that is silent. Given Luhmann's reiterated insistence on separating psychic and social systems, how are we to understand these anthropo able products of the cultur aporia of system closure? " sively creates this aporia. " between society's commur aporia and corresponding At the same time, Luhman the interpenetration and hardly been resolved by th different. Describing his the ple: »But this argumentatic communication often then accustomed to loving certo identifies itself with comm If it is a theoretical error fo mutual confusion by $\gg$ then tion, " it is, nonetheless, ar words, the question as to $\mathrm{w}$ certain words, telling certa a theoretical one. I would a and the figure of the last Logan's oration, are examp provokes the (psychic) ide figure of the sovereign an semantics to stabilize - in »drastic differentiation « fro But what exactly is going $\mathrm{C}$ passingly invokes it above? lary may be helpful here. I relation between the sover touched on the way in whi ures that remark their mu translation of this topolo Lacanian psychoanalysis, does not talk about societ the way the differentiality cation's capacity to utilize ways on Luhmann's theor system and environment, Zizek has elaborated mos which we are concerned. B the subject of the signifie 
mputes sovereignty to the Indian included within the law as aban$y$ affectation that places this repreand mortality. Recall Agamben's it the production of the biopolitical Ner.« The deathless sovereign probody stripped of any significance Who is there to mourn for Logan? 3 , for to be unmourned is to be the andoned by it, the terminus of the includes but leaves alone, its own sovereign exception holds equally, nalyzes, for homo sacer, »the figure $\mathrm{h}$, which is to say, insofar as it is

of the foundational theoretical dis$t$ between social systems and psyes of psychological projection that on (as an attribution of communi$(1995,138 \mathrm{ff})$. To speak, as I have npossibility « risks the confusion of cannot think; a psychological sys102, 165). And surely the silence d of mourning ( $»$ who is there to lamentally different »system refermunication of social systems:

ludes all communication does come a problem... Any other start from the assumption that environment. What is not said :ed by other systems on other pts, metaphors. This does not mains silent. And even this ve of communication and one in reality "silence" is not an a counter-image which society a mirror in which society comes Luhmann 1994, 33)

es with which Luhmann aims to communication, re-enters its own hat is silent. Given Luhmann's reitnd social systems, how are we to understand these anthropomorphizing metaphors? Are these figures unavoidable products of the cultural semantics that have developed to deal with the aporia of system closure? $»$ The sociality of the situational interpretation decisively creates this aporia. This also explains why a ... drastic differentiation between society's communication system and its environment produces this aporia and corresponding efforts in cultural semantics« (Luhmann 1995, 141). At the same time, Luhmann has also readily admitted that the complexities of the interpenetration and co-evolution of psychic and social systems have hardly been resolved by the theoretical decision to describe them as radically different. Describing his theory of communication, Luhmann writes, for example: »But this argumentation naturally needs refinement, since the systems of communication often thematize persons and since consciousness has grown accustomed to loving certain words, telling certain stories, and thus partially identifies itself with communication « $(2002,165)$.

If it is a theoretical error for social and psychic systems to contribute to their mutual confusion by »thematizing persons « or »identifying with communication, « it is, nonetheless, an error of remarkable historical durability. In other words, the question as to why »consciousness has grown accustomed to loving certain words, telling certain stories « is a properly historical question, and not a theoretical one. I would argue, in this regard, that the figure of the sovereign and the figure of the last Indian, so tightly intertwined in my example of Logan's oration, are examples of such »stories « that, by thematizing persons, provokes the (psychic) identification with communication. Put differently, the figure of the sovereign and the last Indian exemplify the effort of cultural semantics to stabilize - include as excluded - the consciousness of society's »drastic differentiation « from its environment.

But what exactly is going on with the concept of »identification « as Luhmann passingly invokes it above? We might ask whether another theoretical vocabulary may be helpful here. In following Agamben's remarks on the inextricable relation between the sovereign exception and the figure of »bare life « we have touched on the way in which the social and the psychic interpenetrate via figures that remark their mutual inaccessibility. I want to conclude now with a translation of this topology into a different theoretical vocabulary, namely Lacanian psychoanalysis, and specifically his concept of identification. Lacan does not talk about society very much, but his conception of the Symbolic as the way the differentiality of language itself enables and constrains communication's capacity to utilize conscious (psychic) systems converges in interesting ways on Luhmann's theory. For here, too, there is a stark divide between the system and environment, a divide that nevertheless must be negotiated. Slavoj Zizek has elaborated most fruitfully Lacanian concepts in the register with which we are concerned. Bringing together Hegel's logic and Lacan's notion of the subject of the signifier, Zizek has outlined how we might read the para- 
doxes of the included exclusion as constitutive of subjectivity itself, as the way in which »the signifier's structure subjectivizes itself «: the »subject only exists within this >failed encounter between the Universal and the Particular - it is ultimately nothing but a name for their constitutive discord « $(1991,46)$. What Zizek here calls »consititutive discord « recalls the »aporia« that Luhmann calls on cultural semantics to either »block or unfold.« Like Luhmann, Zizek's Lacan confronts the primordiality of differentiation: »the starting point ... is not the plenitude of a self-sufficient substance, identical with itself, but the absolute contradiction: the pure difference is always-already the impossible "predicate « of identity-with-itself - or to put it in Lacanian terms, the identity of a signifier's mark (S) always-already represents the subject (/S). This absolute contradiction is »resolved « by way of excluding from the substantial set an element charged with representing the void, the lack of determination that pertains to a tautology; by way of excluding from a series of signifier's marks »at least One « which thereby re-marks the void of their very space of inscription « (Zizek 1991, 48). This exclusion of at least One corresponds to Lacan's (1961) notion that symbolic identification - the identification proper to speaking, communicating beings - depends upon this originary exclusion and reinscription of a single signifier, the »trait unaire « or »one one«. The simultaneity of this exclusion and reinscription of the »one one is what requires, in Agamben's terms, that the sovereign exception - the ideal unity of the nomos - produce, inscribe, literally embody, the homo sacer, or figure of bare life reduced to its pure mortal finitude. For Lacan, this transformation of a void into a unity is the way in which the subject itself is created as metaphor, the subject which, in Lacan's terminology if not in Luhmann's, is the condition of possibility and guarantor of the interpenetration of psychic and social systems. What Agamben's analysis of sovereignty allows us to see is how the political and the psychological enact homologous operations via the topology of the excluded inclusion. Chief Logan's singularity embodies the "one « of the sovereign exception, the ideal unity of the nomos underpinning communication; his »not one« re-marks the impossibility of that operation ever properly starting or coming to an end.

We can I think begin to see why the figure of the last Indian in the American archive is both so contradictory and so durable. The last one, as I have shown, always means both less than one and more than one. In this way it suspends a political practice of extinction that it announces as inevitable. The figure of »bare life« must be kept alive, must keep reappearing so as to disappear; in this respect, the political practice most closely associated with the trope of the »last Indian « is not genocide, but the "reservation. (As an ethical matter, however, this might be called a difference that does not make a difference). I have described the operation at work in this figure in a variety of ways, but let me offer one more: In blocking the paradox involved in the establishment of sovereignty, Logan's »not o1 insofar as the contradiction 53), »it is >repressed, $<>$ push one that can never be over, $\mathrm{c}$ is there to mourn for Logan? repression that must be unc munication. Repressions are less« linkages for further $\mathrm{c}$ how society chatters ceasel of the silence that sustains $i$

\section{References}

Agamben, Giorgio (1998): Hom University Press.

Alexandrowicz, Charles H. (196\% the East Indies $\left(16^{\text {th }}, 17^{\text {th }}\right.$, and

Boyd, Julian P. (1938): Indian Tr phia: Historical Society of Per

Burke, Joseph C. (1996): The Pp. 136-67 in: Native Americ Garland Publishing.

Cooper, James Fenimore (1986 [

Deloria, Vine, Jr. (1988 [1969]): University of Oklahoma Pres

Elmer, Jonathan (1998): The Ar Diacritics 28.4, 5-24.

Foucault, Michel (1990 [1976]): York: Vintage Books.

Hardt, Michael / Negri, Antonio

Harring, Sidney L. (1994): Crow United States Law in the Nin

Jefferson, Thomas (1982 [1785]) North Carolina Press.

Koselleck, Reinhart (1988 [1959] of Modern Society. Cambridg

Kroeber, Theodora (1961): Ishi: Berkeley: University of Califo Lacan, Jacques (1961): Seminair

Locke, John (1980 [1690]): Seco ing.

Luhmann, Niklas (1994): Speak

Luhmann, Niklas (1995 [1984]):

Luhmann, Niklas (2002): Theor nity. Stanford: Stanford Univ

Pagden, Anthony (1986): The Fa Comparative Ethnology. Lon

Prucha, Francis Paul (1994): An Berkeley: University of Calif 
tive of subjectivity itself, as the way izes itself «: the »subject only exists Universal and the Particular - it is nstitutive discord « $(1991,46)$. What lls the »aporia that Luhmann calls c unfold.« Like Luhmann, Zizek's rentiation: »the starting point ... is tance, identical with itself, but the e is always-already the impossible ut it in Lacanian terms, the identity represents the subject (/S). This $y$ of excluding from the substantial the void, the lack of determination cluding from a series of signifier's arks the void of their very space of on of at least One corresponds to ification - the identification proper ends upon this originary exclusion strait unaire, « or »one one«. The ription of the "one one " is what areign exception - the ideal unity of ibody, the homo sacer, or figure of . For Lacan, this transformation of a ubject itself is created as metaphor, $f$ not in Luhmann's, is the condition netration of psychic and social syseignty allows us to see is how the ologous operations via the topology agularity embodies the »one nomos underpinning communicaility of that operation ever properly

e of the last Indian in the American rable. The last one, as I have shown, than one. In this way it suspends a lounces as inevitable. The figure of reappearing so as to disappear; in sely associated with the trope of the eservation.« (As an ethical matter, that does not make a difference). I is figure in a variety of ways, but let ox involved in the establishment of sovereignty, Logan's »not one « could be described as »repressed.«»Precisely insofar as the contradiction is absolute, real-impossible" « writes Zizek (1991, 53), »it is >repressed, < >pushed away < into a timeless past «. A timeless past is one that can never be over, one that can never be processed as an event: "Who is there to mourn for Logan? - Not one. «The endurance of this figure signals a repression that must be understood at the level of the social system of communication. Repressions are not black holes of incommunicability, but »timeless « linkages for further communication. A »real-impossible« mourning is how society chatters ceaselessly in response to its own repressed knowledge of the silence that sustains it.

\section{References}

Agamben, Giorgio (1998): Homo Sacer: Sovereign Power and Bare Life. Stanford: Stanford University Press.

Alexandrowicz, Charles H. (1967): An Introduction to the History of the Law of Nations in the East Indies $\left(16^{\text {th }}, 17^{\text {th }}\right.$, and $18^{\text {th }}$ Centuries). London: Oxford University Press.

Boyd, Julian P. (1938): Indian Treaties Printed by Benjamin Franklin, 1736-1762. Philadelphia: Historical Society of Pennsylvania.

Burke, Joseph C. (1996): The Cherokee Cases: A Study in Law, Politics, and Morality. Pp. 136-67 in: Native American Law and Colonialism, Before 1776 to 1903. New York: Garland Publishing.

Cooper, James Fenimore (1986 [1826]): The Last of the Mohicans. New York: Penguin.

Deloria, Vine, Jr. (1988 [1969]): Custer Died for Your Sins: An Indian Manifesto. Norman: University of Oklahoma Press.

Elmer, Jonathan (1998): The Archive, the Native American, and Jefferson's Convulsions. Diacritics $28.4,5-24$.

Foucault, Michel (1990 [1976]): The History of Sexuality: An Introduction. Volume I. New York: Vintage Books.

Hardt, Michael/Negri, Antonio (1999): Empire. Cambridge: Harvard University Press.

Harring, Sidney L. (1994): Crow Dog's Case: American Indian Sovereignty, Tribal Law, and United States Law in the Nineteenth Century. Cambridge: Cambridge University Press.

Jefferson, Thomas (1982. [1785]): Notes on the State of Virginia. Chapel Hill: University of North Carolina Press.

Koselleck, Reinhart (1988 [1.959]): Critique and Crisis: Enlightenment and the Pathogenesis of Modern Society. Cambridge: MIT Press.

Kroeber, Theodora (1961): Ishi: A Biography of the Last Wild Indian in North America. Berkeley: University of California Press.

Lacan, Jacques (1961): Seminaire sur l'Identification (1961-62), unpublished typescript.

Locke, John (1980 [1690]): Second Treatise of Government. Indianapolis: Hackett Publishing.

Luhmann, Niklas (1994): Speaking and Silence. New German Critique 61, 25-37.

Luhmann, Niklas (1995 [1984]): Social Systems. Stanford: Stanford University Press.

Luhmann, Niklas (2002): Theories of Distinction: Redescribing the Descriptions of Modernity. Stanford: Stanford University Press.

Pagden, Anthony (1986): The Fall of Natural Man: the American Indian and the Origins of Comparative Ethnology. London: Cambridge University Press.

Prucha, Francis Paul (1994): American Indian Treaties: The History of a Political Anomaly. Berkeley: University of California Press. 
Schmitt, Carl (1996 [1950]): The Land Appropriation of a New World. Telos 109, 29-80.

Twain, Mark (1967): Fenimore Cooper's Literary Offenses. Pp. 169-181 in: Great Short Works of Mark Twain. New York: Harper \& Row.

Zizek, Slavoj (1991): For They Know Not What They Do: Enjoyment as a Political Factor. London:Verso.

Assoc. Prof. Jonathan Elmer, Department of English, Indiana University 442 Ballantine Hall, 1020 E. Kirkwood Ave., Bloomington, IN 47405-7103 jelmer@indiana.edu
Oliver Marchart.

\section{On Drawing A Line Politics and the Signifi}

Abstract: The article investigate figure of drawing a lines. The $m$ modulated in the works of Mao, as in popular culture. Yet sdrawi the article is that this figure inv nature of society, the necessity of problematic of the subject along

- $\gg$ This is not about rev - »Liar! «

- »This is about saving - $\gg$ Jean-Luc, throw up - »No! Nooo! « (music sets in)

- $\gg I$ will not sacrifice th already, too many retr They assimilate entire must be drawn here. $\mathrm{Tl}$

One need not be a speciali the previous dialogue in $v$ the »Star Trek-universe «. ) sion/ exclusion by invoking - at the beginning of this »politics of popular cultur present a Cultural Studie class-relations in the Starthe legitimacy of such an a reduce it to a cliché versi approach in this paper di Trek - First Contact as a cul tasies evoked by such text itly political text, a version 